\title{
Analysis of Damper Effect on Cable-Stayed Bridge Using Finite Element Simulation
}

\author{
(Analisis Kesan Peredam Terhadap Jambatan Berkabel Menggunakan \\ Simulasi Unsur Terhingga) \\ Chai Mei Hwa* \& Siti Aminah Osman
}

\begin{abstract}
Cable-stayed bridges generally having common defects such as excessive vibration due to wind action, corrosion and fatigue occurred at the cables supporting member. This study presents two different approaches for the demonstration of the damping effect due to wind action on cable-stayed bridge. The first approach uses a simplified analysis method to study the reaction force at the cable end. A beam element was adopted for modelling the cables and a plate element for modelling the bridge's deck. The second approach is based on the selected damper system applied at the cable end to determine the reaction response at the bridge models. Two methods are presented in this report with the consideration of bridge geometric effect. The effect of pretension of the cable and the exact treatment of cable sag with the cable weight is ignored. A numerical calculation has been carried out in determining the nominal transverse wind load, the nominal longitudinal wind load on deck and the nominal longitudinal wind load on cables in accordance to the current code of practice. The results generated from MIDAS Civil software have been used for comparing the analysis results. The stiffness coefficient for the selected rubber damper type was being modelled at the cable end to examine the effect of nominal and combined wind action at critical locations. The effectiveness of using the rubber damper to suppress the effects of wind was investigated through superposition of these rubber dampers at the maximum reactions at the cable end. It was found that the damper system adapted on the cable-stays has significant influence on suppressing the action due to wind.
\end{abstract}

Keywords: Cable-stayed bridge; rubber damper; MIDAS Civil

\section{ABSTRAK}

Jambatan berkabel umumnya mempunyai kecacatan biasa seperti getaran yang berlebihan disebabkan oleh tindakan angin, kakisan dan keletihan berlaku pada kabel sokongan ahli. Kajian ini membentangkan dua pendekatan yang berbeza untuk demonstrasi kesan redaman akibat tindakan angin atas jambatan berkabel. Pendekatan pertama menggunakan kaedah analisis ringkas untuk mengkaji daya reaksi di hujung kabel. Elemen rasukyang diterima pakai untuk pemodelan kabel dan unsur plat untuk pemodelan dek jambatan. Pendekatan kedua adalah berdasarkan sistem peredam terpilih yang digunakan di hujung kabel untuk menentukan reaksi tindak balas pada model jambatan. Dua kaedah yang dibentangkan dalam kajian ini dengan pertimbangan kesan geometri jambatan. Kesan prategasan kabel dan rawatan tepat kendur kabel dengan berat kabel diabaikan. Pengiraan berangka telah dijalankan dalam menentukan beban angin melintang nominal, beban angin membujur nominal geladak dan beban angin membujur nominal pada kabel mengikut kod semasa dan amalan. Keputusan yang dihasilkan dari perisian MIDAS Civil telah digunakan untuk membandingkan keputusan analisis. Pekali kekukuhan untuk jenis peredam getah yang terpilih adalah yang dimodelkan di hujung kabel untuk meneliti kesan daripada tindakan angin nominal dan gabungan di lokasi-lokasi kritikal. Keberkesanan menggunakan peredam getah untuk menyekat kesan angin dikaji melalui posisi tindakbalas maksimum pada peredam getah di hujung kabel. Didapati bahawa sistem peredam yang digunakan pada jambatan berkabel berpontensi mempengaruhi kesan angin yang bertindak ke atasnya.

Kata kunci: Jambatan berkabel; peredam getah; MIDAS Civil

\section{INTRODUCTION}

The damping effect of the cable dampers are used for the suppression of wind-induced loadings of stay cables in cable-stayed bridges. For this study, a computer simulation showing a cable damper is being installed on cables system aiming to increase its serviceability life of cables due to wind forces. High damping rubber bearing (HDRB) consist of thin layers of high damping rubber and steel plates built in alternate layers. In order to reduce wind-induced loadings, it is note that the cable dampers are installed with the aims to reduce amplitudes caused by the force acting on the cables. Considering the damper stiffness and damping coefficient of the rubber, the damper model is assumed to add effective damping and stiffness to cable structure. Therefore, the properties of high damping rubber produced by Doshin Rubber Sdn. Bhd. are being considered in relation of its stiffness and damping capacity for this study. The first 
objective of this study is to demonstrate an example of a simplified three dimensional finite element bridge structure with the effects of longitudinal wind loads on cables by using MIDAS Civil software. The simplified cable-stayed bridge model was designed to carries 2 carriageway (4 lanes) over a river. To date, not much has been published on the effects of cable dampers are being placed at the end of a cable for bridge structures. As for cable-stayed bridge, longer steel cables will be more sensitive to dynamic excitation.

The damping capacity is difficult to predict in order to sufficiently eliminate cable vibrations. Conventional elastomeric or friction dampers along the cables may not be sufficiently allowed real time reaction of the damping device to the occurring vibrations. The second objective is to illustrate the effects on the high damping rubber bearing (HDRB) which are being placed at the end of the cable for the analysis. The dimension of HDRB damper shall be individually adapted to the cable requirement. For the simulation purposes, special geometries are applied to the model. The study of wind effects is normally conducted by separating the static component, associated with a mean flow velocity of air, and the dynamic component, related with vortex shedding and atmospheric turbulence. It is note that a variety of windinduced vibrations to stay cables has become an onerous issue and many of the cable-stayed bridges are now built with crossties between cables, oil or visco-elastic dampers attached to the lower end of the stay cables to minimise the effects caused by the wind. Also the performance of unidirectional tuned liquid damper that rellies upon the motion of shallow liquid in a rigid tank for changing the dynamic characteristic of a structure and dissipating its vibration energy under harmonic excitation (Modi et al. 1995).

\section{ANALYTICAL APPROACH}

The finite element simulation model is concerned about the study of the effects of cable damper on cable-stayed bridges. The presented bridge model has a symmetrical span with double plane of cables. Semi-harp pattern is adopted for the longitudinal layout of cable stays. The ultimate goal of the analysis is to obtain the reactions at the cable ends due to the effects on longitudinal wind loads. A twin shape tower was used in the analysis to obtain stiffness against wind load which the cable transfers to top of the towers. The pylon is fixed at the foundation to support the superstructure. This arrangement reduces bending moments in the pylons and simplifies analysis of the overall structure. The cables for the bridge model are made from steel. The cable is a basic element in cable-stayed bridge. The apparent axial stiffness of the cable stay in a cable-stayed bridge is affected by the cable sag which is greatly influenced by the amount of tension in the cable (Aschrafi \& Hirsch 1984). It is one of the basic elements in cable-stayed bridges. The cable adopted in the simulation has a high tensile strength of $260.7 \mathrm{kN}$ per strand and a high elastic modulus of $195 \mathrm{kN} / \mathrm{mm}^{2}$. The strand prestressing tendons shall be 7 -wire low relaxations having physical properties such as a strand diameter of $15.2 \mathrm{~mm}$ and a nominal cross-sectional area of $140 \mathrm{~mm}^{2}$ per strand. The cables are good to resist tensile force but weak against compression and bending forces. In practice, Steel cables may allow a slender structure to cater longer spans or distances. It is also observed that the combined use of high-damping rubber and oil dampers is an effective counter measure for the rain-wind induced vibrations in comparison to the rubber dampers (Takano et al. 1997).

The bridge deck model consists of a composite steel girder with reinforced concrete bridge structure. The structural purpose of the deck is to carry longitudinal and transverse bending moments due to self-weight and associated loadings such as dead and super-imposed dead loads, live traffic loadings, wind and seismic loadings. In modelling, the stiffness of the bridge deck is important as the results generated from the MIDAS Civil software may influenced by the distribution point loads to cable in relation to the deck's stiffness. As a results of wind loading is always a significant loading for the structural design of cable-stayed bridge, the other loadings are therefore not considered in the simulation. In general, wind pressure on bridge depends on the geographical location, the heights of the bridge, and the horizontal dimensions and cross section of the bridge element under consideration. The maximum wind gust speed on bridge is derived from mean hourly wind speed. The adopted mean hourly wind speed is $40 \mathrm{~m} / \mathrm{sec}$. The starting point for both methods is to determine the basic hourly mean wind speed at a height of $10 \mathrm{~m}$ in a particular location being exceeded of 0.02 annual risk ratios with a mean recurrence interval of 50 years (Wenjun 2010). A wind pressure of $6 \mathrm{kN} /$ $\mathrm{m}^{2}$ is applied to the vertical projected area of the bridge and in this case the pylons of the cable-stayed bridge are under consideration. Pursuant to Clause 5.3.2.1: Maximum Wind Gust Speed $V_{d}$ of BD37/01, the maximum wind gust, $V_{d}$, can be calculated by Equation 1 .

$$
V_{d}=v K_{1} S_{1} S_{2}
$$

The adopted values for $v=40 \mathrm{~m} / \mathrm{sec}, K_{1}=1.0, S_{1}=1.1$ and $S_{2}=1.81$. The estimated wind gust, $V_{d}$ is equal to $79.64 \mathrm{~m} / \mathrm{sec}$. The nominal transverse wind load, $P_{t}$ is given by Equation 2 and is acting perpendicular to the side of the bridge.

$$
P_{t}=0.613 V_{d}^{2} A_{1} C_{D}
$$

The adopted values for $V_{d}^{2}=6342.53 \mathrm{~m} / \mathrm{sec}, A_{1}=75 \times$ $2=150 \mathrm{~m}^{2}, C_{D}=1.2$ (ratio $b / d=16.4 / 2=8$ ) in accordance to Figure 4 of BD37/01. The estimated transverse wind load, $P_{t}$ is equal to $0.7 \mathrm{kN} / \mathrm{m}^{2}$. An upward or downward nominal vertical wind load $P_{v}$, acting on the bridge deck is derived from Equation 3.

$$
P_{v}= \pm q A_{3} C_{L}
$$

The adopted values for $q=0.613 V_{d}^{2}=3887.97 \mathrm{~m} / \mathrm{sec}$, $A_{3}=75 \times 48=3600 \mathrm{~m}^{2}, C_{L}=0.38($ ratio $b / d=16.4 / 2=8)$ in accordance to Figure 5, Lift Coefficient $C_{L}$ of BD37/01 - Loads for Highway Bridges. The vertical wind load, $P_{v}$ is 
equal to $\pm 5.32 \mathrm{kN} / \mathrm{m}$. The nominal longitudinal wind load, $P_{L}$ is the sum of the nominal longitudinal wind load on the superstructure, $P_{L S}$ and the nominal longitudinal wind load on the live load, $P_{L L}$ with the nominal longitudinal wind load on parapets, $P_{L}$ can be calculated in Equation 3, 4 and 5.

$$
\begin{gathered}
P_{L S}=0.25 q A_{1} C_{D} \\
P_{L L}=0.5 q A_{1} C_{D} \\
P_{L}=0.8 P_{t}
\end{gathered}
$$

The adopted values for $q=0.613 V_{d}^{2}=3887.97 \mathrm{~m} / \mathrm{sec}$, $A_{1}=75 \times 48=3600 \mathrm{~m}^{2}, C_{D}=1.2($ ratio $b / d=16.4 / 2=8)$ in accordance to Figure 4 of BD37/01. Therefore the $P_{L S}$ is equal to $4.20 \mathrm{kN} / \mathrm{m}$, the $P_{L L}$ is equal to $8.40 \mathrm{kN} / \mathrm{m}$ and the $P_{L}$ is equal to $0.56 \mathrm{kN} / \mathrm{m}$. The total nominal longitudinal wind load on the bridge deck is $P_{L S}+P_{L L}+P_{L}=12.96 \mathrm{kN} / \mathrm{m}$. The nominal longitudinal wind load on the cable can be calculated based on Equation 7.

$$
P_{L C}=0.5 \rho V_{d}^{2} C_{D} D L
$$

The adopted values for $V_{d}^{2}=6342.53 \mathrm{~m} / \mathrm{sec}, \rho$ is the air density equal to $1.25 \mathrm{~kg} / \mathrm{m}^{3},{ }^{C} C_{D}=1.2$ (ratio $b / d=16.4 / 2=$ 8 ) in accordance to Figure 4 of $\mathrm{BD} 37 / 01, D$ is the diameter of the cable which is taken as $154 \mathrm{~mm}$ and $L$ is the length of the cable that taken as $41 \mathrm{~m}$. The estimated longitudinal wind load on cable, $P_{L C}$ is equal to $30.04 \mathrm{kN}$. In summary, the calculated wind loads is as below:

1. Nominal Transverse Wind Load, $P_{t}=0.70 \mathrm{kN} / \mathrm{m}^{2}$

2. Nominal Vertical Wind Load, $P_{v}= \pm 5.32 \mathrm{kN} / \mathrm{m}$

3. Nominal Longitudinal Wind Load on Deck, $P_{L}=12.96$ $\mathrm{kN} / \mathrm{m}$

4. Nominal Longitudinal Wind Load on Cables, $P_{L C}=30.04$ $\mathrm{kN}$

\section{MODELLING}

The simplified model for the cable-stayed bridge is shown in Figure 1. It includes structural elements such as the bridge deck, the tower and the cables. The cables are modelled as a rigid bars connecting to the bridge deck. The cable-stayed system is in equilibrium under its self-weight. The model consists of 326 nodes; 14 tower elements, 20 cable elements and 300 girder elements. Based on the MIDAS Civil software, the tower and the cable is model as a beam element, and for the segmental box girder, it is model as a plate element. Figure 2 showing Elastic link is introduced between cables and bridge deck for the cable-stayed bridge model in the MIDAS Civil software.

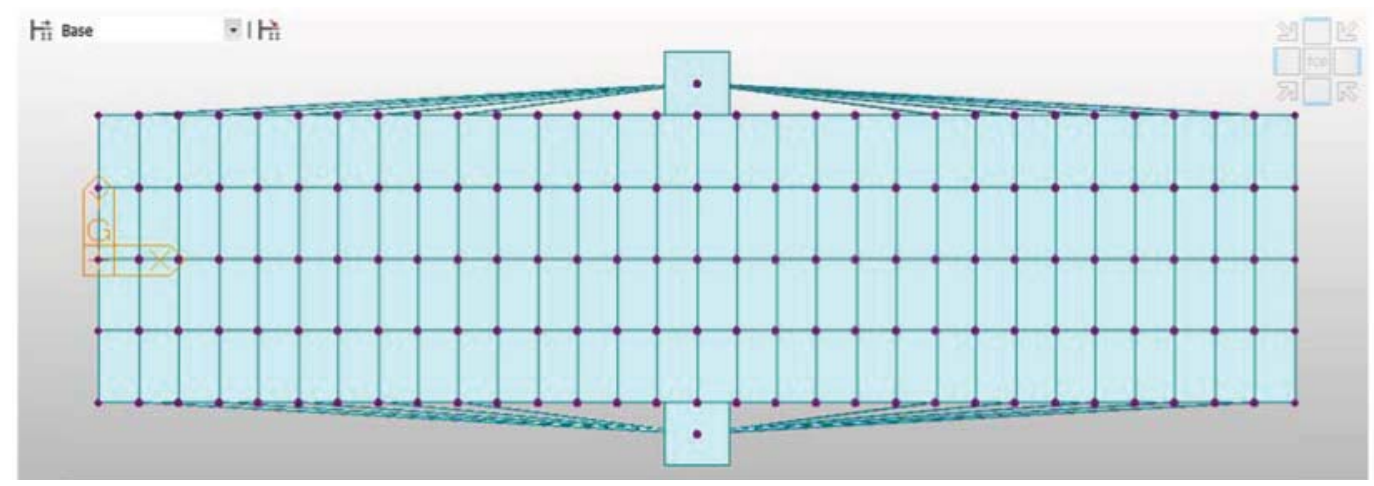

FIGURE 1. Plan view of the bridge deck indicated with the nodes

The geometry adopted for the cable-stayed bridge model is often crucial as the dimension properties such as height, length and width of the bridge will influence the results in determining the overall reaction force due to the wind load. Basically the model has two plane semi-harp pattern cables supported by a dual concrete tower with a main span of 75 meters. There are 10 numbers of cables at one side of the tower connecting with the deck and the tower is 48 meters high. Both the tower and the bridge deck are made of grade 50 concrete. The superstructure is a segmental box girder with a section of 18 meters wide and 2.5 meters deep. The longest cable stayed of the bridge is 41 meters. The support conditions of the model are fixed support at the tower base, pinned support at both ends of the bridge deck and rigid support between the bridge deck and the tower. The MIDAS
Civil 2015 version 1.1 software is compatible in analyse a numerous analysis for the load distribution. The software can generates the finite differences and hence determine the reactions for the superstructure at the connection between the cables and the segmental box girder. Based on the computer analysis, a finite plate element is adopted to calculate the stiffness for the bridge deck.

\section{FINITE ELEMENT SIMULATION RESULTS AND DISCUSSIONS}

For the analysis of the model, the cables are modelled as a rigid beam. The cable-stayed system has to be in equilibrium under its own weight. When applying the preliminary loadings for the cables, the bridge deck interacts with the tower and causing deformations on the cables. The support 


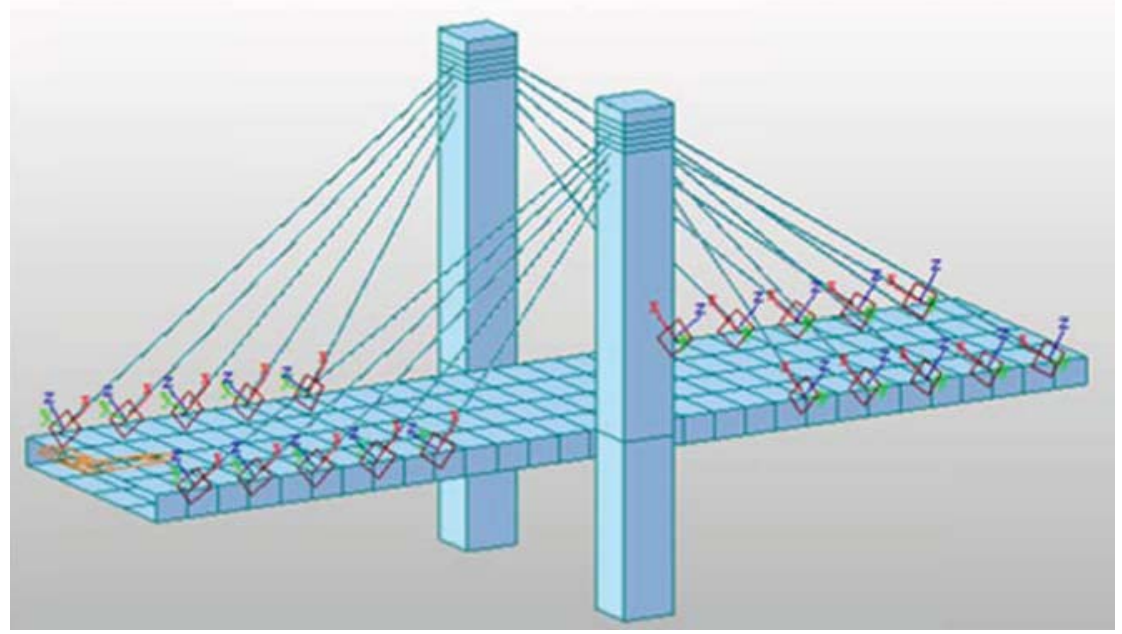

FIGURE 2. Elastic link is introduced between cables and bridge deck

conditions and the stiffness of the structural components play an important role in determining the reaction force acting on the cable. This study was carried out based on the design code of practice for the design loads due to wind effects on bridges for static load cases application on the model. Figure 3 and 4 shows the stresses obtained from the MIDAS bridge model without cable damper for wind load on cable only and wind load combination load cases respectively.

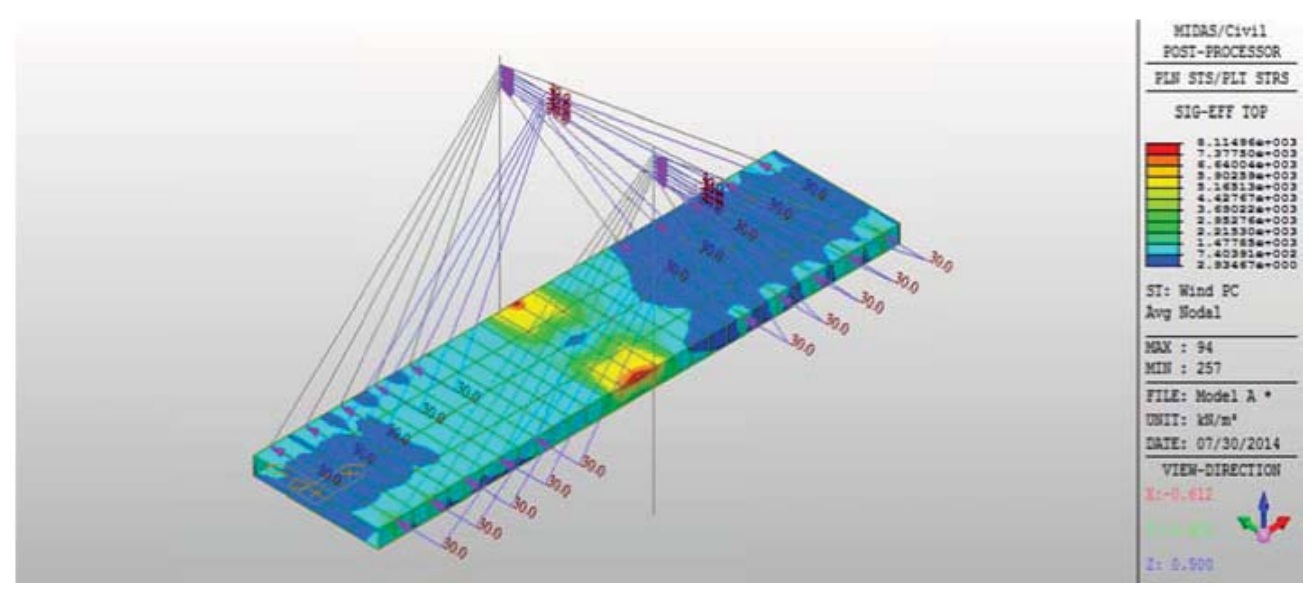

FIGURE 3. Maximum stresses with wind $P_{C}$ only applied on the cable without damper

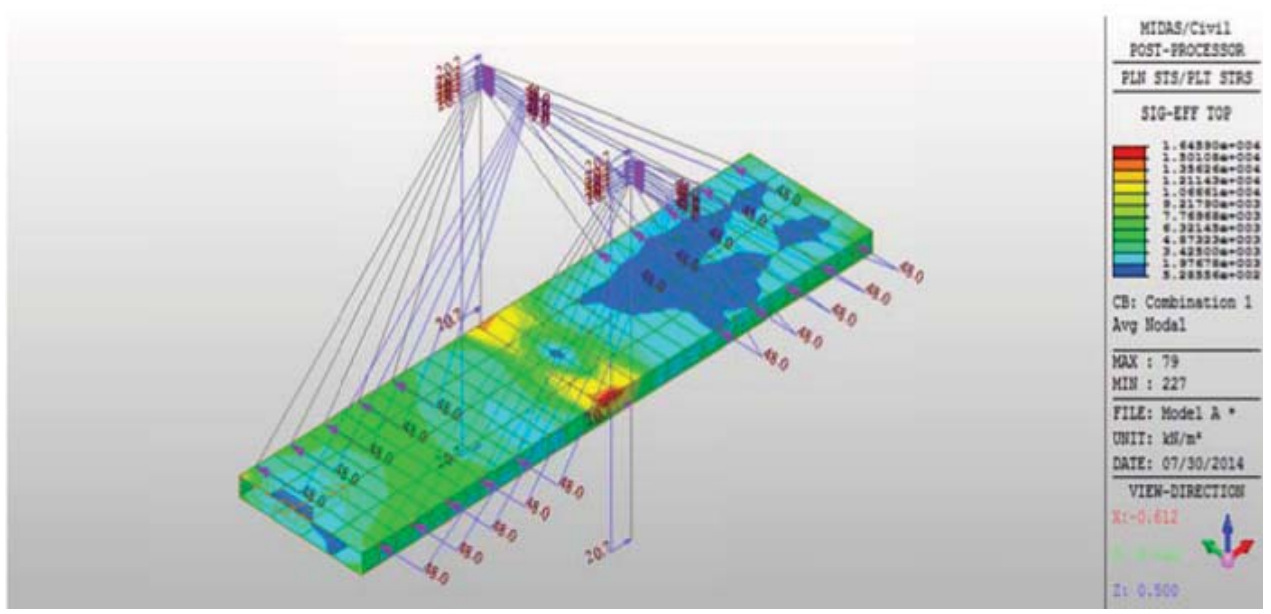

FIGURE 4. Maximum stresses with combination load cases 1 on the cable without damper 
For the analysis of the model with the application of elastic link being placed at the cable, the support conditions and the stiffness of the structural components changed. Figure
5 and 6 shows the stresses obtained from the MIDAs bridge model with cable damper for wind load on cable only and wind load combination load cases respectively.

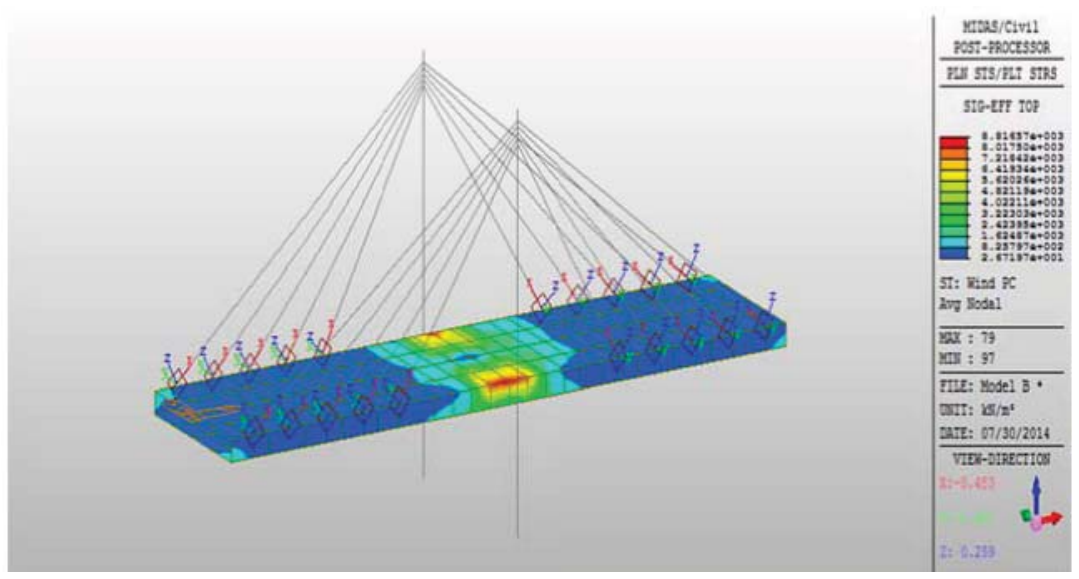

FIGURE 5. Maximum stresses with wind $P_{C}$ only applied on the cable with damper

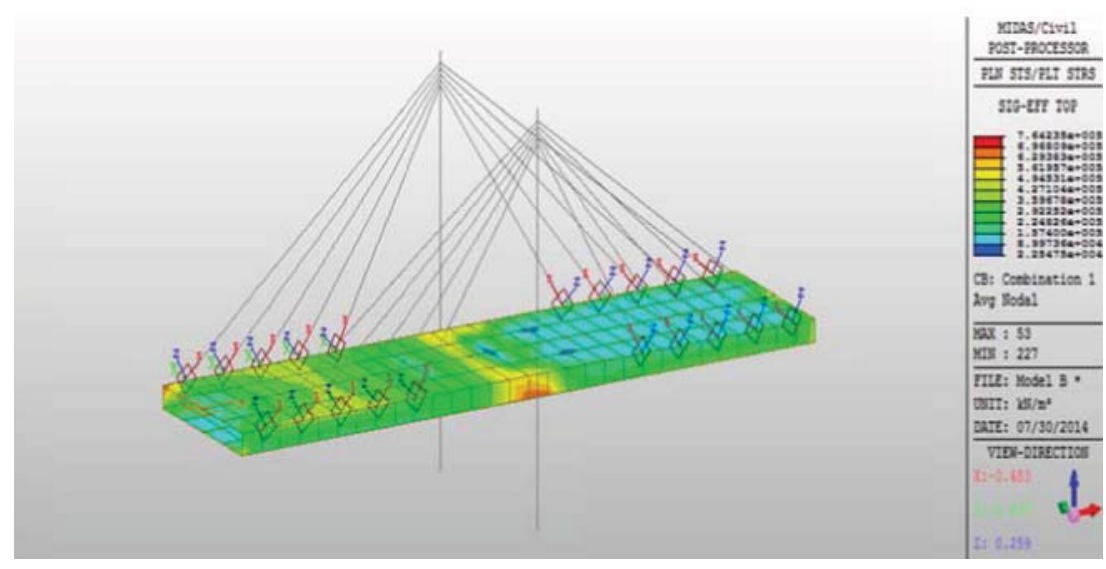

FIGURE 6. Maximum stresses with combination load cases 1 on the cable with damper

Upon completion of the simulation of a simplified three dimensional finite element modelling, the interpretation of the maximum reaction results is shown on Table 1 . It is expected the simulation results for the cable without damper is having a higher reaction force and stress in comparison to the cable with damper. It is noticeable that the stiffness introduced at the cable end has attracted higher forces in wind load combination of dead load, nominal transverse wind load, nominal longitudinal wind load on deck and the nominal longitudinal wind load on cables.
For this study, rubber damper is selected for the mode of the analysis. The rubber damper consists of several highdamping rubber pads which are normally installed inside the cable casing between the cable and the steel tube at the bridge deck anchorage. The cable vibration due to wind loads is absorbed by shear deformation of the rubber pads. A simplified analysis was carried out for the preliminary design of the rubber dampers. In accordance to Doshin Rubber Sdn. Bhd. Catalogue, the high damping rubber bearing provide a vertical stiffness of $824 \mathrm{kN} / \mathrm{mm}$ based on vertical load of $100 \mathrm{t}$.

TABLE 1. Comparison table for cables reaction with and without damper

\begin{tabular}{lccc}
\hline Elements & Reaction force $(\mathrm{kN})$ & Stress $\left(\mathrm{kN} / \mathrm{m}^{2}\right)$ & Displacement $(\mathrm{m})$ \\
\hline Wind load on cables with damper & $344 @$ element 354 & $1.95 \mathrm{e} 4$ & $0.1519 @$ node 28 \\
Wind load on cables without damper & $386 @$ element 22 & $2.19 \mathrm{e} 4$ & $0.1623 @$ node 28 \\
\hline
\end{tabular}


The high damping rubber bearing has a design displacement of $270 \mathrm{~mm}$ which 14 nos of rubber layer. The size of the rubber is $500 \mathrm{~mm}(D) \times 220 \mathrm{~mm}(H)$. The target period $(T D)$ is 3 seconds with a design displacement of $150 \%$ shear strain and a shear modulus of 0.4-0.6 MPA. The main parameters that are believed to cause the differences in the reaction and stresses response in cable-stayed bridge's cable are:

1. Geometric proportions of the bridge. For longer cable compared to bridge length, the present model will give higher solutions due to the length of the cable being calculated for the nominal longitudinal wind load on cables.

2. Location of the point studied along the cables. Different location may also influence the studying of the response of a point situated between two cables instead of a point to a cable.

\section{CONCLUSION}

A more realistic wind loads such as the dynamic effects cannot be predicted including the damping effect with variable traffic loading configurations and the flexural rigidity of the bridge deck. The results obtained indicate that the wind effects on the cable are based on the equations in accordance to BS5400 Part 2:2006 - Steel, Concrete and Composite Bridges Specification for Load, as adopted in many of the current bridge design codes. This study has shown that the elastic link at the cable elements can attract significant forces under load combination. In order to protect the cable by providing damping across all modes of vibration and with no moving parts, high-damping rubber (HDR) or super-damping rubber (SDR) are ideal for cable-stayed bridge with short to medium cable length or cables with moderate damping requirements (Takano et al. 1997; Minoru et al. 1999). This makes the damping stiffness may change the reaction force at any cable stays. It has been demonstrated that the cable-stayed bridge with damping system applied on the cable have a damping effect with respect to the applied wind load.

However, it is observed that a highly nonlinear behaviour may occur during the dynamic impact of the wind load. Also the cable surface roughness may have a significant effect on the dynamic response. For a more detailed and accurate study, a true dynamic response is required which includes the consideration of cables motion and the modes of vibration in the dynamic analysis. The damping stiffness should be carefully estimated to ensure an accurate representation of the true behaviour of the cable-stays under the wind action. Also there are some methods which combined the usage of rubber and oil dampers or viscous shear damper to achieve the results (Seo et al. 2002). The characteristics of highdamping rubber, its application and damping mechanism design method have been described with several studies been carried out into the effectiveness of methods using dampers (Nakamura et al. 1998). In order to obtain a realistic damping stiffness, a field tests or experiments should be carried out on actual cable-stayed bridge. The effect of cable modelling and the dampers should be more thoroughly investigated using a more realistic damping stiffness data and parameters with the consideration of cable surface roughness and actual bridge geometry. For future research it is suggested to simulate the model based on actual statistical field results obtained from site for the stiffness value. Extensive testing on the cable damping should be performed to assess the validity of the analysis in conjunction to the simulation findings. Research is needed to thoroughly study the damper's parameters on its effect to suppress the wind load.

\section{REFERENCES}

Aschrafi, M. \& Hirsch, G. H., 1984. Control of wind-induced vibration of cable-stayed bridges. Wind Engineering 1983: 235-246.

Doshin Rubber Products (M) SDN BHD - High Damping Rubber Bearings \& Lead Rubber Bearings for Buildings and Bridges.

Minoru, M., Sinji, M. \& Takashi, H. 1999. The Super High Damping Rubber Damper on the Stay-cables of Meiko East Bridge. IABSE reports page 131-132.

Modi, V. J., Welt, F., \& Seto, L. M. 1995. Control of windinduced instabilities through application of nutation dampers: A brief overview. Engineering Structure (17)9: 626-638.

Nakamura, A., Kasuga, A. \& Arai, H. 1998. The effects of mechanical dampers on stay cables with high-damping rubber. Construction and Building Materials (12)2-3: 115-123.

Seo, J., Kim, N., Ha, D. \& Suh, J. 2002. Development of cable damper with high damping rubber bearing for cable stayed bridge. Structural Dynamics. Eurodyn 2002, Grundmann \& Schueller. Swets \& Zeitlinger, Lisse, ISBN $905809510 \mathrm{X}$.

Takano, H., Ogasawara, M., Ito, N., Shimosato, T., Takeda, K. \& Murakami, T. 1997. Vibrational damper for cable of the Tsurumi Tsubasa Bridge. Journal of Wind Engineering and Industrial Aerodynamics 69-71: 807-818.

Wenjun, X. 2010. A critical analysis of sutong Yangtze highway bridge. Proceeding of Bridge Engineering 2 Conference 2010.

Chai Mei Hwa* \& Siti Aminah Osman

Department of Civil and Structural Engineering

Faculty of Engineering and Built Environment

Universiti Kebangsaan Malaysia

43600, UKM Bangi, Malaysia

Phone: +03 89216228

*Corresponding author; email: chaimeihwa@gmail.com

Received date: $22^{\text {nd }}$ September 2014

Accepted date: $7^{\text {th }}$ January 2015 